\title{
IN MEMORIAM PROFESSOR SÁNDOR TUBOLY
}

(1932-2017)

Sándor Tuboly, professor emeritus, professor and former head of the Department of Microbiology and Infectious Diseases, Doctor (DSc) of the Hungarian Academy of Sciences, honorary doctor of the University of Veterinary Medicine, member of the Editorial Board of Acta Veterinaria Hungarica died on 16 June 2017.

Sándor Tuboly was born to a family of teachers in Hercegfalva in 1932. He obtained his general certificate of education from the 'Szent István' Cistercian secondary school of Székesfehérvár in 1950. He continued his studies at the University College of Veterinary Science where he received his doctor's diploma in 1955. His interest in microbiology and infectious diseases manifested itself already during his undergraduate years: he got the first inkling of research when working with his project leader, Professor Tamás Szent-Iványi as an undergraduate participating in the activities of the Scientific Students' Association. After graduating from the university, he worked in the practice as a state veterinarian for six years, and then over a period of 15 years he acted as a veterinary specialist and subsequently a department head at the Central Veterinary Institute, where he did outstanding diagnostic and research work. He participated in the eradication of many infectious diseases of high economic importance, such as tuberculosis and brucellosis. The experiences that he gained as a veterinary practitioner and as a specialist working at a diagnostic institute always formed part of his lectures, which thus became very personal. He was invited to work at the Department of Microbiology and Infectious Diseases of the University of Veterinary Science by Professor Tamás Szent-Iványi in 1976. At that department, he worked as a senior research worker (1976), Associate Professor (1979) and Full Professor (1988) pursuing both teaching and research, and between 1990 and 1998, until his retirement, he also acted as head of the department. He maintained relations with the department on a regular basis even after his retirement: as a professor emeritus, he regularly gave lectures that were followed with great interest by the students, guided students preparing their diploma works, participated in veterinary specialist training, and was a regular invited speaker at postgraduate training courses held in different counties of Hungary.

It was Professor Sándor Tuboly who organised the immunology training of undergraduates at the University of Veterinary Science; over a period of many years he was the lecturer of immunology and epizootiology at the University, and he wrote many university lecture notes and textbooks on the subject. He was editor and co-author of the textbooks 'Veterinary Epizootiology, Volume I - Veterinary Microbiology', 'Infectious Diseases of Domestic Animals', 'Vaccinology: The Immunoprophylaxis of Infectious Diseases of Domestic Animals', and the Spanish-language 'Manual de Microbiología Veterinaria'.

Professor Sándor Tuboly made use of his professional knowledge also in his wide-ranging international co-operations. As an invited specialist, he participated in the development of diagnostic methods for infectious diseases on multiple occasions, over a period of many years; he also pursued research and directed the work of $\mathrm{PhD}$ candidates. Many times he conducted several weeks' long microbiological courses in Cuba, held lectures on exotic animal diseases at the Veterinary Faculty of the Universidad Complutense of Madrid, and was a guest professor and lecturer of infectious diseases at the University of Cáceres during a whole semester on five occasions. In the framework of different international co-operations he took study trips to, or exchanged experiences in, Austria, Germany, Poland, Vietnam, Angola, Mozambique, Russia, Mexico, Spain, Sweden and the United States. 
Professor Sándor Tuboly conducted wide-ranging research: his studies on tuberculosis, the genus Mycobacterium, the ontogenesis of the immune system, the humoral and cellular immune response of newborn animals, acquired immunodeficiency syndromes, and the intestinal absorption of colostral lymphocytes attracted great international interest. Based on the results of these works, in 1969 he obtained the degree Candidate in Veterinary Science with his dissertation entitled 'Comparison of the antigenic structure of pathogenic and saprophytic mycobacteria', and then in 1982 he earned his Academic Doctor's (DSc) degree with his thesis 'Ontogenesis of the immune system'. Sándor Tuboly summarised his research results in more than 150 scientific papers.

Professor Sándor Tuboly played a key role in the Hungarian and international professional public life: he was an executive board member and, during several cycles, the secretary of the Hungarian Society for Microbiology, President of the Hungarian Society for Veterinary Immunology, President and Vice President of the Hungarian Society of Zoonoses, and member of the Committee on Veterinary Science of the Hungarian Academy of Sciences. He was an Editorial Board member of the journals Veterinary Immunology and Immunopathology, Journal of Veterinary Medicine and Acta Veterinaria Hungarica. He participated in the public life of the University by acting as a member of the Senate over several cycles and as chairman of the Senior Teacher and Researcher Forum (1989-1996).

Sándor Tuboly's work was recognised by many awards: he received the 'Rezső Manninger Memorial Medal' from the Hungarian Society for Microbiology, the 'Högyes-Aujeszky Memorial Medal' from the Hungarian Society of Zoonoses, the UNEX Memorial Medal for Education from Extremadura University in Spain, and the 'József Marek Memorial Medal' and the 'Tree of Life Prize' from the University of Veterinary Medicine. However, perhaps the greatest recognition that he received was the distinction 'The Best Teacher of the Year', which was awarded to him by the students as many as 10 times.

Professor Sándor Tuboly was a teacher to the core: even in possession of his professional experience encompassing several decades, he always conscientiously prepared for his lectures, which were constructed so as to address all listeners. Teaching and lecturing were an invigorating force for him even when his health had started to decline.

Professor Sándor Tuboly lived a full life in all respects. He took pleasure in all his duties: the veterinary practice, the diagnostic work, teaching, research and postgraduate training were not a burden for him at all, as he could do what he really liked. This full professional life was supported by a loving family: over a period of 60 years his wife provided him with a strong and affectionate background, which greatly contributed to his professional success. He had great joy in watching the careers and success of his children and grandchildren. He took especially great pleasure in the achievements of his son, Tamás Tuboly, who became his worthy successor as a professor at the University of Veterinary Medicine.

With Sándor Tuboly's death we have lost a great scientist, an excellent teacher, a successful researcher and a true, warm-hearted colleague. We should regard it as a special gift from life that we could be his students, co-workers and colleagues. His life, work, personality and scale of values may serve as a model for us and for the future generations alike.

May God rest his soul in eternal peace!

László Fodor and Péter Sótonyi 